\title{
Chapter 9 \\ Quality Assurance in Online Learning \\ at Scale at the Indonesia Cyber \\ Education Institute
}

\author{
Paulina Pannen
}

\section{Abbreviations}

HEI higher education institution

ICE Institute Indonesia Cyber Education Institute

ICT information and communication technology

MOOC massive open online course

MORTHE Ministry of Research, Technology and Higher Education

SPADA Sistem Pembelajaran Daring

UNESCO United Nations Educational, Scientific and Cultural Organization

\subsection{Introduction}

The rapid growth of information and communication technology (ICT) has led to the impressive growth of online higher education worldwide. In general, adoption and implementation of online education is aimed at enhancing the quality of teaching and learning to accommodate various learning styles of students, increase access to learning opportunities, increase the learning flexibilities for students to develop skills and competencies needed in the twenty-first century, and improve cost effectiveness of the institution. Online education provides an opportunity for anyone to learn anytime, anywhere; and to communicate and collaborate virtually across countries. Through the use of technology in online education, education is considered to

\footnotetext{
P. Pannen ( ()

Ministry of Research and Technology/National Agency for Research and Innovation, South

Tangerang, Indonesia

e-mail: ppannen@ristekbrin.go.id; paulina@ecampus.ut.ac.id
}

Faculty of Education, Universitas Terbuka, South Tangerang, Indonesia

S. Ra et al. (eds.), Powering a Learning Society During an Age of Disruption,

Education in the Asia-Pacific Region: Issues, Concerns and Prospects 58,

https://doi.org/10.1007/978-981-16-0983-1_9 
be delivered more efficiently and at a lower cost. For many higher education institutions (HEIs), online education is beneficial to reach new student markets needing flexible learning opportunities, as well as to provide an opportunity for creating new innovative learning environments.

In the conventional setting, online education has been integrated into a blended learning mode that allows a mix of online and offline learning within a course, or within a curriculum. What was once a sporadic individual effort of a faculty member to improve learning through flexible and media-rich teaching and learning has been evolving into institution-wide, even country-wide programs from which students can obtain both credits and degrees (Pannen 2015). Although online education is considerably new and is a different practice of teaching and learning in HEIs, it is expected to deliver significant improvements, specifically increased access to quality higher education at reduced costs to meet the same goals, satisfy the same requirements, and achieve the same learning outcomes as conventional education.

The use of online learning has been amplified by the coronavirus disease (COVID-19) pandemic that requires people to apply social distancing and less-contact activities. Schools and HEIs have been closed. For Indonesia, learning was $70 \%$ conducted from home in 2020, with the remaining 30\% allowed only for small group meetings, particularly for practices and practicum, while applying health protocols. Even in the red zone area, the Minister of Education and Culture has advised postponement of practices and practicum until the new semester in 2021.

The learning from home or "emergency remote learning" has been heavily reliant on the use of ICT, especially e-learning systems and virtual meeting mobile applications. Some HEIs had an advantage, having prepared their e-learning courses prior to the pandemic in preparation for the fourth industrial revolution or Industry 4.0. With the sudden shift to learning from home, the use of ICT for teaching and learning is now inevitable. This has in turn posed questions about the quality of learning from home, which may be more flexible for students but less controlled by lecturers. By its nature, the flexible and virtual mode of online education demands evidence of higher quality than that of conventional education (Protopsaltis and Baumi 2019). It is necessary for online education to prove its quality to be comparable to conventional education.

This paper discusses the development of online education in Indonesia and highlights the effort of the Government of Indonesia at quality assurance of online education, and quality education in a learning from home situation.

\subsection{Development of Online Education in Indonesia}

Higher education is at the forefront of Indonesia's policy to prepare the country for Industry 4.0. With a gross domestic product of \$1,022,454 million as of 2019, ${ }^{1}$

\footnotetext{
${ }^{1}$ Source countryeconomy.com. Indonesia GDP_gross domestic product. https://countryeconomy. com/gdp/indonesia?year=2019.
} 
Indonesia is the world's seventh largest economy in purchasing power parity terms, and has the world's fourth largest population of 272.1 million. ${ }^{2}$ The government is determined to improve Indonesia's competitiveness in the world market, placing high priority on the development of science, technology, and innovation as demanded by Industry 4.0, and infusing humanist and inclusive goals into its tertiary education program. According to the Ministry of Research, Technology and Higher Education (MORTHE), the goal is to increase the gross tertiary enrollment from $34 \%$ (8 million students) to $50 \%$ (11.7 million) by 2024 (MORTHE 2019a). Currently, Indonesia has 4,583 HEIs with 34,189 study programs and 286,787 lecturers. ${ }^{3}$ The government expects online education to play a significant role in the development of competent, skilled, and professional human resources to meet the needs of industry and the community in the twenty-first century, especially given the increasingly technology-savvy Indonesian population. The country's internet penetration in 2019 has reached $64 \%$, while social media users comprise $59 \%$, and mobile users $124 \%$ of the population of 272.1 million (2019). ${ }^{4}$

In this paper, online education is defined as education delivered or accessible via the use of ICT, including its connectivity, flexibility, and ability to promote varied interactions. Online education covers e-learning, distributed learning, networked learning, tele-learning, virtual learning, web-based education, distance education, technology-based education, massive open online courses (MOOC), blended learning, flipped learning, and also learning from home using ICT during the COVID-19 pandemic. The last falls under the broader category of technology-based education, which can be delivered in blended mode in a conventional face-to-face education setting, or in a distance education mode.

Technology-based education in Indonesian higher education has a long history and has been growing impressively. It started as a traditional correspondent course for teachers' education in the early 1950s. In 1984, the establishment of Universitas Terbuka introduced multimedia distance education marked by computer-based education, tele-education, internet-based education, and web-based education. At present, Indonesia is making efforts to apply blockchain technology for its online higher education (see Fig. 9.1).

By 2014, Indonesia was promoting online learning through Indonesian MOOCs called Sistem Pembelajaran Daring (SPADA Indonesia), consolidating individual faculty efforts in about 4,000 HEIs. SPADA Indonesia started with 30 online courses from six pioneer universities, shareable to more than 4,000 HEIs. The first batch of students was around 3,000 with a completion rate of $61 \%$ and average retention rate of 42\% (Pannen 2015; Pannen and Riyanti 2017; Chaeruman 2018). Although SPADA Indonesia was less successful compared to the Hybrid Learning for Indonesian

\footnotetext{
${ }^{2}$ Source Worldometer. Indonesia population. https://www.worldometers.info/world-population/ind onesia-population/.

${ }^{3}$ Source Pangkalan Data Perguruan Tinggi (Higher Education Database). https://pddikti.kemdik bud.go.id/.

${ }^{4}$ Andi.Link. Hootsuite (we are social): Indonesian digital report 2020. https://andi.link/hootsuitewe-are-social-indonesian-digital-report-2020/.
} 


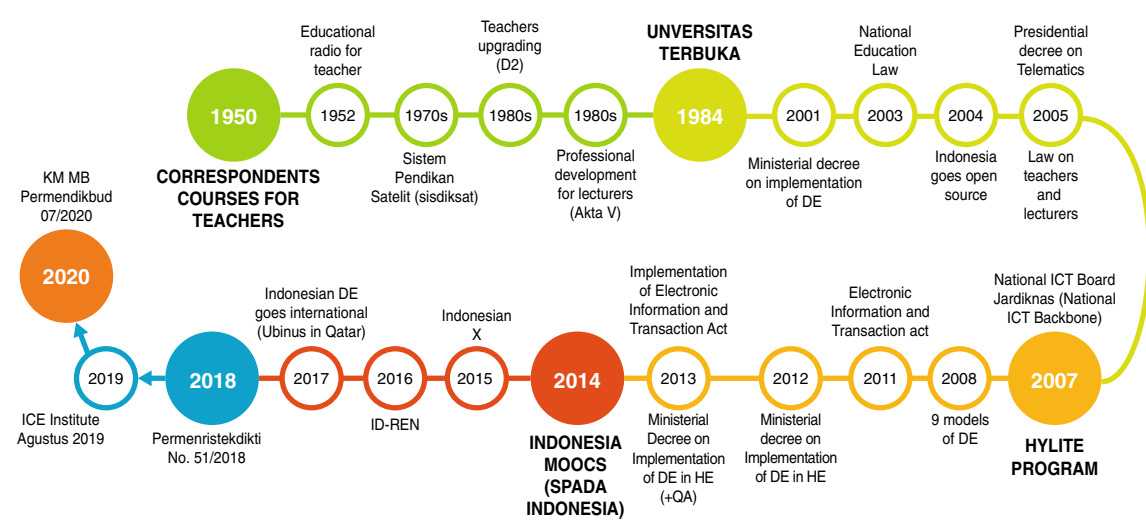

Fig. 9.1 Development of technology-based education in Indonesia (Milestones in technology-based education in Indonesia). Source Adapted from P. Pannen, and R.D. Riyanti. 2017. Digital and distance learning in higher education in Indonesia: Moving forward. Paper presented at the International Council for Open and Distance Education World Conference on Online Learning Teaching in a Digital Age-Re-thinking Teaching and Learning. 16-19 October 2017. Toronto

Teachers (HYLITE Program), which had a success rate of 90\%, SPADA Indonesia was relatively more successful than the pilot test of Coursera, which logged $7 \%$ completion (Rivard 2013).

SPADA Indonesia has expanded its course collection since 2014. By the end of 2019, there were 279 open content, 221 open courses, and 400 online courses offered by 54 HEIs to 201 partners, involving 15,138 students. Since 2017, SPADA Indonesia has also been hosting a 1-year teachers professional course consisting of more than 600 modules from 53 study programs, involving 18,103 participants, conducted in 58 teacher colleges (Pannen 2019). SPADA Indonesia has also supported in-country student mobility by allowing students to do "one semester in other university", and offering joint courses among the seven HEIs in Indonesia on special topics such as disaster management, peatlands, and tropical diseases.

The government's initiative was soon followed by private sector initiatives. The Indonesia-X applies an EdX model for Indonesian online courses using instructional video from various distinguished Indonesian scholars. It is open and free to participate in, but exams and certification are fee-based. At one point, Indonesia-X had about 5,000 students taking a popular marketing course. Haruka Edu is another private player in the online education market in Indonesia.

In early 2020, a new policy was issued by the Minister of Education and Culture that allows HEIs to apply Kampus Merdeka-Merdeka Belajar (Freedom Campus-Freedom Learning). This allows undergraduate students to have three semesters of independent study to conduct several activities for credit transfer, including two semesters off-campus, and one semester cross-credit from other study programs and/or faculties within the HEI. The off-campus study covers internships, practices, community projects, teaching, research, entrepreneurship activities, humanity projects, and or independent projects, including online courses 
from other HEIs or aggregators. The one semester cross-credit study has encouraged online courses to flourish, and is preferred by both students who prefer to learn from, and lecturers who prefer to teach, online study programs in other campuses.

While online education is developing rapidly in Indonesia, the program needs an enabling regulation and quality assurance system to scale up. In terms of regulations, the newest ministerial regulation on distance education of 2020 includes regulations on online education in a conventional university, a distance education university, and an unbundled university setting (fully online as well as blended learning). This opens opportunities for HEIs to offer online courses or online study programs. It has also led to the establishment of more online higher education institutions such as the University of Cyber Asia, which was launched in September 2020, offering fully online programs.

The new Regulation No. 7/2020 assumes that advancement of technology to include artificial intelligence will provide strong support for the development of online education in Indonesia. This new regulation virtually enables online education to exist with the transfer of credentials from other HEIs. During the pandemic, this policy allowed online courses to increase up to $70 \%$. Parallel to this, the Government of Indonesia has issued a new policy to open up its market for cross-border education, especially to commercial presence of foreign HEIs in Indonesia, covering physical branch campus, or collaboration presence or virtual presence. It can be expected that more online education from foreign universities will soon be offered.

Indonesian HEIs also enter foreign markets. In 2017, Universitas Bina Nusantara opened its distance education center in Qatar, offering five study programs related to industrial engineering and information technology to more than 100 Indonesian workers. Meanwhile, Universitas Terbuka has representatives in 40 countries to cater to Indonesians abroad needing higher education. Thus far, two HEIs are offering single mode distance and online education, the Universitas Terbuka and University Cyber Asia. Further, there are 11 HEIs offering 58 distance education study programs, including 40 programs of Universitas Terbuka, 6 vocational programs from National Polytechnics of Electronics in Surabaya, and Health and Medical Polytechnics in Kupang and Samarinda.

Regulation No. 7/2020 also introduces a new framework for quality assurance to cover not only accreditation in institutions and/or study programs in the conventional and distance education settings, but also accreditation in courses and blocks in an online or unbundled university setting. As part of the scheme, a national quality assurance center was created by the Government of Indonesia to ensure quality of online education regardless of level (institution, study program, course, or block). Called the Indonesia Cyber Education Institute (ICE Institute), the center was designed to house all online courses and online education in Indonesia and ensure quality in the marketplace of online education in Indonesia. ICE Institute will focus mainly on online education and will complement the existing Badan Akreditasi Nasional Pendidikan Tinggi (National Accreditation Agency of Higher Education) or BAN-PT. 


\subsection{Quality Assurance in Online Education in Indonesia}

In order to achieve the goals of access, quality, and relevance of tertiary education, Indonesia is promoting alternative and complementary education delivery vehicles of distance education through the use of online learning technology. It is believed that distance education will increase the participation rate in higher education and thus achieve equity, improve the overall quality of higher education, provide instant access to global Industry 4.0 knowledge and innovations, and promote lifelong learning and opportunities for reskilling and up-skilling of workers.

Nevertheless, one major issue in online education has been its quality. Stakeholders of HEIs have always compared online education to conventional education. Online education is not simply different ways of packaging instruction, nor modeling conventional classroom practice and focusing on the presentation and delivery of content, nor an electronic copy of traditional face-to-face education. The ultimate test of online education - in any form - will be learning effectiveness. Content can be easily duplicated in various formats, including e-learning, but may not have value. What is valuable is the interaction; the synergy; and the bonding of students, faculty members, tutors, resources, and the institutions through personal feedback and assessment, contextualized and personalized navigation through complex topics, encouragement, questioning by a faculty member and/or tutor to promote deeper thinking, and a context and infrastructure of learning (Allen and Seaman 2013). Theoretically, there is a minimum standard to be fulfilled as a guarantee that the online education process will be well implemented. This requirement typically defines levels of minimum acceptability for particular dimensions for the quality of institution, study program, or course.

In 2014, along with the inauguration of SPADA Indonesia, a team was appointed to implement quality assurance for all online courses under SPADA Indonesia. This was meant to control quality in every single online course to be offered through SPADA. The framework involves six domains of indicators: (i) instructional design, (ii) content, (iii) interaction and delivery process, (iv) assessment and evaluation, (v) system and technology, as well as (vi) human resources (Pannen 2019). Since online courses are offered by existing accredited institutions and study programs, they were not considered for evaluation anymore.

The quality control indicators were focused heavily on the proposed design of online learning experience, which is different in nature and process from conventional learning. Also, assessment is done on "system and technology" as intrinsic requirements, which constitute a high capital investment. Advocacy on sharing system was provided by the government to reduce initial costs in setting up distance education. Human resources are also being assessed for technology literacy and online pedagogy skill of instructors and tutors. The HEIs participating in SPADA were allowed to revise and improve their online courses so as to adhere to the intrinsic requirements (MORTHE 2019b). That marked the first time a course became an entity in quality assurance in higher education in Indonesia. 
Although distance education in Indonesia higher education has been around for quite some time since 1984, the minimum requirement and accreditation tools for distance (online) education were completed only in 2019, especially for distance and online education study programs (MORTHE 2019b). Within the tools, the National Accreditation Agency has included indicators for blended and online course in conventional universities, and a separate instrument for distance (online) education. The accreditation conducted by the National Accreditation Agency is focused on an institution and study program to assess the quality of implementation. Meanwhile, quality assurance of online courses requires a more systematic integrated assessment mechanism conducted prior to implementation of the online courses.

Facilitated by Regulation No. 51/2018 and No. 7/2020, MORTHE has encouraged HEIs to start online courses. The number of proposals for online course as well as new online study programs have been increasing. These proposals are reviewed by Directorate General of Higher Education for provision of license to operate. Once it passes the review, the courses or study programs can be offered. It is assumed that good quality plans will lead to good implementation and good results.

\subsection{Indonesia Cyber Education Institute}

Quality assurance in online education is highly strategic for online education. Without standardized quality assurance, stakeholders evaluate effectiveness and ineffectiveness based on their own perception, which may be biased. Online education has allowed HEIs to provide different certificates and degree-awarding strategies using blockchain, micro credentialing, or digital credentialing. Thus, quality assurance of online courses is highly important to make a course transferrable across HEIs as well as across countries, as it will ensure quality and integrity in online course credentials earned in various higher education institutions.

The ICE Institute was established for the transformation of higher education in Indonesia in response to Industry 4.0 (MORTHE 2019c). The establishment of ICE Institute under the auspices of MORTHE is very timely, since there is growing interest in online education in public and private HEIs in Indonesia, as well as foreign HEIs coming to Indonesia virtually. The ICE Institute was inaugurated in August 2019, and is managed Universitas Terbuka. In its first stage, several HEIs are collaboratively building the marketplace based on common standards.

The architecture of ICE Institute is depicted in Fig. 9.2.

The function of ICE Institute is first, to curate online courses or online study programs in Indonesia, specifically the e-learning courses from Indonesian universities, as well as online courses from international universities and global MOOC platforms. As the online courses enter the online market, quality assurance is mandatory. ICE Institute will be able to carry over the curation process and supervise its compliance based on certain standards. In this process, curation is not merely looking for validity of the content and reviewing the design of online learning experience, but also examining the interoperability of each course within 


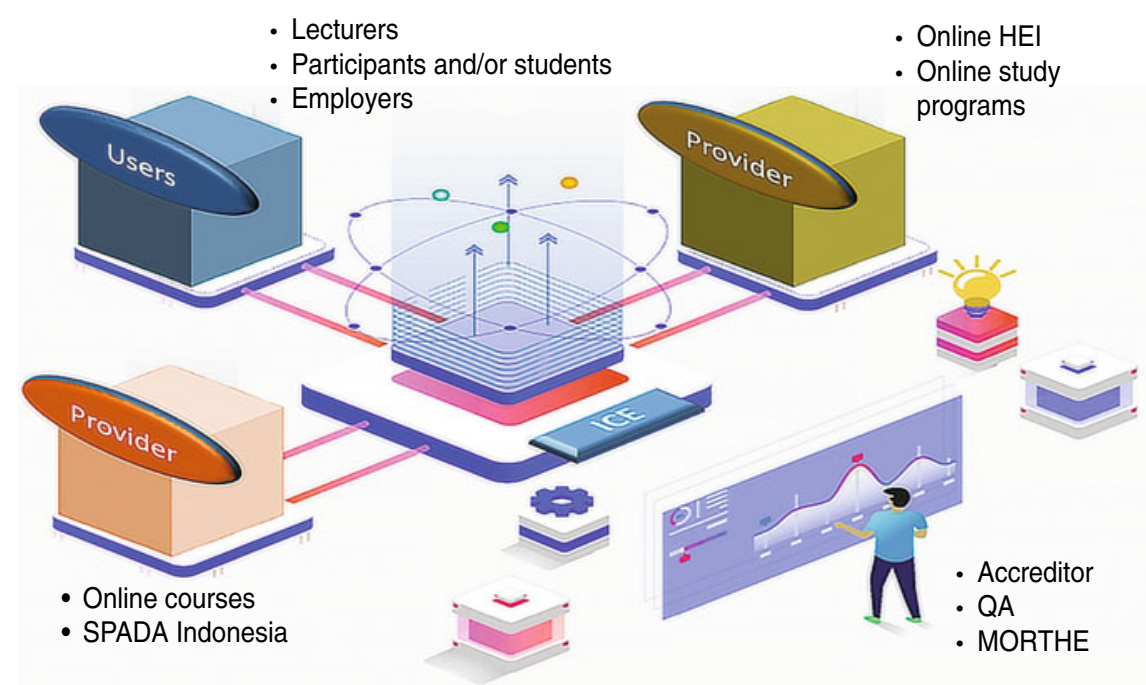

Fig. 9.2 Architecture of the Indonesia cyber education institute (ICE Institute is expected to offer wider access to high-quality higher education, and to serve as a vehicle for credit transfer, degree programs, continuing professional development, and lifelong learning for all Indonesian people) . HEI = higher education institution, MORTHE = Ministry of Research, Technology and Higher Education, QA = quality assurance. Source Ministry of Research, Technology and Higher Education. 2019c. Arsitektur konseptual ICE Institute: proses - aplikasi - database - teknologi. Concept paper presented by Pannen, P. ICE Institute Development Team Chairman, to the Minister of Research, Technology and Higher Education. May 2019

the ICE Institute system and marketplace. Afterward, a registration number will be assigned as the unique identity for the marketplace of the ICE Institute.

Managing the marketplace of online education is the second function of ICE Institute. Employing blockchain for its services, the marketplace of the ICE Institute will have a number of galleries, i.e., the website of the HEIs, SPADA Indonesia, as well as international online course providers. Quality assurance in online courses in the marketplace will facilitate course and credit transfers, or recognition across institutions or countries.

In addition, ICE Institute is expected in the future to also house online course learning management platforms to assist HEIs that do not own platforms. By the very nature of its operation, ICE Institute owns big data on students taking online courses, which can be used for further analysis to improve online courses offerings as well as the ICE Institute's services. The blockchain technology will also allow the ICE Institute to provide a general ledger on students' records for each of their individual transactions in online education mode.

A study by Gullapalli and Ren (2019) confirms the need for quality assurance in online education systems up to the course or block level. Their study indicates that for $76 \%$ of recruiters, online education requires regional accreditation to be recognized as equal to conventional education. Mostly, recruiters value online 


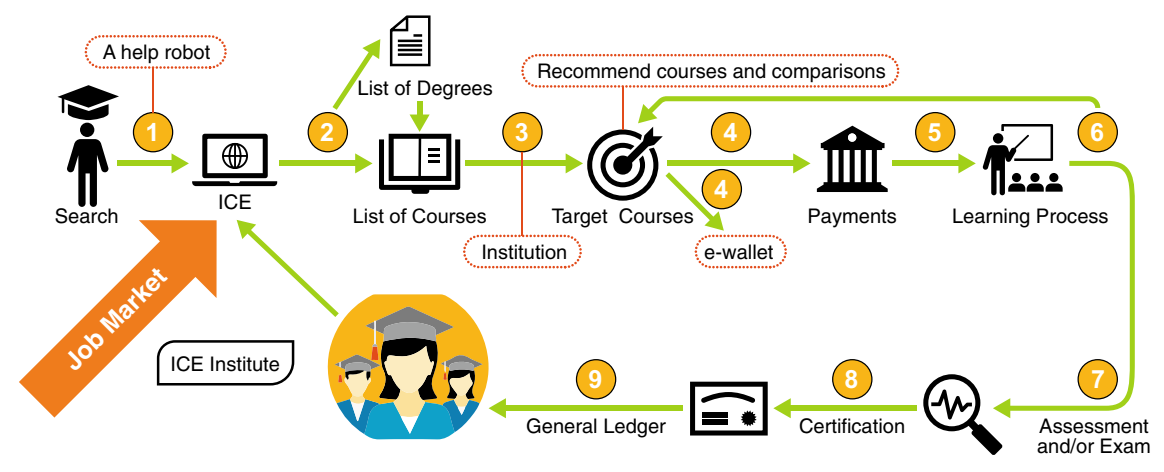

Fig. 9.3 Business process of the Indonesia Cyber Education Institute (For the ICE Institute, quality assurance is needed in each step of the process). Source Gullapalli, S., and P. Ren. 2019. ICE Institute and digital education in Indonesia. Presentation to the Ministry of Research, Technology and Higher Education by Darden School of Business, University of Virginia. 19 December 2019. Jakarta

courses from "well-known" or accredited HEIs (Fig. 9.3). Starting with the ICE-I website (appearance, chatbot, navigation, content), the intrinsic requirements for quality online courses consist of design and development of the learning journey, learning materials, delivery system, interaction and/or engagement strategy, and assessment and evaluation. The next considerations are quality of administration, including registration, payment, e-wallet, announcement and notification, general ledger, student record, linkages with other websites such as job market platform, etc. While the learning process and assessment or exam are to be assured by each participating HEI, the certification process and the value of the certificate have to be assured by the ICE Institute.

\subsection{Quality Assurance of Online Education in Southeast Asia and Beyond}

The development of online education in Indonesia has taken an almost similar course to that of other Southeast Asian countries, such as Malaysia, the Philippines, Thailand, and Viet Nam. The Association of Asian Open University has launched a MOOCs collection produced by its members, and the Asian University Network.

Thailand's online education was initiated in 2017 by the Thai Cyber University Project as the national MOOC platform in Thailand (Theeraroungchaisri and Khlaisang 2019). The main target groups of Thai MOOCs are employees, entrepreneurs, students, teachers, and others from the general public. In 2019, nine universities collaborated to develop Thai MOOC, resulting in a total of 300 courses; 2,470 learning hours; and more than 94,000 participants (Theeraroungchaisri and 
Khlaisang 2019). The Thai MOOC introduces "credit bank" concept as application of blockchain in education to offer flexible lifelong learning opportunity for Thais.

In the Philippines, the University of the Philippines Open University or UPOU was established in 1995 applying fully online open distance learning. Since 2013, UPOU has promoted Massive Open Distance and E-Learning (MODEL) to provide more open and accessible education, and to reach out to more Filipinos not just in the Philippines but all over the world. UPOU offers certification based on completion of an online course to participants coming from local government, as well as businessmen, workers, and specific target groups, who enjoy flexibility in the offerings.

Meanwhile, in Malaysia, development of online education is exemplified by Taylor University, which started its first online course in the form of MOOC in 2013. This was followed by four universities i.e., Universiti Teknologi Malaysia, Universiti Teknologi MARA, Universiti Malaysia Sarawak, and Universiti Kebangsaan Malaysia. In 2014, the government declared Malaysia as the first country in the world to implement MOOCs for all public universities, and also the only country where MOOCs are implemented at a national scale through the local government (Rajendram 2014). Malaysian MOOCs are focused not only on academic courses, but also on nonformal and informal interests, and flexible courses for lifelong learning.

Today, each country seems to carry out its own initiatives in online education, mostly in the form of MOOCs or e-learning. In general, this movement in online education is based on the aim to offer educational opportunities to a wider audience in a more flexible manner and affordable cost. Most initiatives enjoy strong government's support, which require fulfillment of certain standards to serve majority of the public. The United Nations Educational, Scientific and Cultural Organization (UNESCO) reports that pushed by the COVID-19 pandemic, the campus-based universities in virtually every country worldwide is transitioning into online learning (UNESCO 2020a, b).

With such intensive practice of online education to reach wider audiences, providing a seamless opportunity for education in a very short time, sometimes without proper preparation, especially during this pandemic, places the quality of online education at risk. In this case, ICE Institute has the capability to provide guidance for quality online courses especially through the curation process, which will assist online education providers in conducting quality control and assurance. Further, with the online education movement, transfer of courses across institutions within a country or across countries may become a common practice, which can be facilitated through the online course marketplace. This marketplace for online education will be a primary tool for Asian countries to exchange quality courses within a micro credentials framework. Through collaboration, ICE Institute can become a hub to assist HEIs in Southeast Asia and beyond to widen their reach across institutions as well as countries. 


\subsection{Quality Assurance of Online Education During the Coronavirus Disease Pandemic}

In an era of increased accountability, it is important to be able to demonstrate that online education adoption is sound, effective, and efficient. The COVID-19 pandemic has had significant consequences on higher education institutions. Conventional universities need to adjust to the disruption and carry out the whole learning experience from home, heavily using technology.

Since the spread of the pandemic, technology-based education or online education has gained high popularity in Indonesia. Belawati and Nizam (2020) confirm that Indonesian HEIs have undergone digital transformation through adoption of "online learning" after Indonesia enforced limited social movement. Within less than a month, $98 \%$ of 4,621 Indonesian HEIs have gone into online learning. In the capital city of Jakarta, about $65 \%$ of 325 HEIs reported directly deploying online learning for emergency remote learning. Prior to the pandemic, less than $10 \%$ of HEIs employed online learning for up to $30 \%$ of its curriculum. Such a sudden shift to online education, without proper preparation, lowers the expectation of the outcome of the emergency remote learning situation.

Within 2 months after the Government of Indonesia declared a lockdown due to the pandemic, around 60\% of HEIs' efforts have been focused on preventive actions, such as issuance of policy for emergency remote learning; introduction of health and social protocols; deployment of masks, disinfectant, and hand sanitizers; and maintenance of communication. Changing teaching and learning activities, issuance of new policies regarding remote learning from home, as well as the postponement of practices or practicum came afterward. The emergence of COVID-19 left little room for HEIs to fully prepare the online courses, the system, the lecturers, and the students for an online learning mode. A study by Belawati (2020) suggests that HEIs took 25 days to move into online learning since the outbreak, with $76 \%$ of lecturers and $46 \%$ of students reported having experienced online learning. Belawati (2020) also indicates that the Google online learning platform was highly popular, followed by modular object-oriented dynamic learning environment or MOODLE, and Microsoft Teams or MS Teams. As for discussion, Zoom has been a popular platform. Meanwhile, majority of online learning materials are reported to be in the form of PowerPoint, MSWord, portable document format, and video, either as developed by the lecturers or taken from the internet. Although online and blended learning were perceived to be complicated at first, up to $75 \%$ of lecturers and $43 \%$ students reported willingness to continue online and blended learning in the future.

In the evolving new normal, less-contact teaching and learning in the form of online learning will become common practice in most HEIs, and may replace or be blended with the traditional classroom teaching and learning. Quality offering of the online learning experience is indispensable. While each HEI takes steps in quality assurance of its online courses, deploying ICE Institute's services in curating the online courses, offering of high-quality online courses through its marketplace, and employing ICE Institute's general ledger on student data will be a useful option for HEIs in Indonesia. 


\subsection{Conclusions}

The current environment brought about by COVID-19 has shown the rapid growth of online education, which comes with some challenges, especially the issue of assuring quality of online courses. With students facing a lot of academic constraints in online education offered especially during the pandemic, only quality online courses can compensate the situation. Each online course must go through quality curation through a systematic and reliable mechanism to assure its design quality, its content, as well as its interoperability. Such mechanism must be made available within each country and applied by each HEI offering online courses. Spending time to wait for market evaluation toward the online courses is not advisable as learning experience as well as time for students will be jeopardized. Thus far, the mechanism for assuring quality of online courses is mostly integrated in the mechanism of quality assurance for a study program or a HEI, not as a separate or unbundled entity. The ICE Institute is one of the mechanisms that will curate specifically online courses in Indonesia prior to their offering, thus guaranteeing the quality of the courses.

The establishment of ICE Institute shows the vision and commitment of the Government of Indonesia in promoting the quality of online education in Indonesia. Moving into the future, ICE Institute needs to develop its blockchain technology that would allow the institute to offer more flexible and transferrable online courses, which are linked to the registration and verification credit system in HEIs, to the skills set database, and to the job market. The presence of ICE Institute may also create a new tertiary education and employment ecosystem that one, incorporates advanced AI-powered labor market information system between HEIs and industry; and two, uses AI-powered student career guidance for employability. Through rigorous quality assurance, online courses in the ICE Institute marketplace will be able to gain regional or even international accreditation to assure regional or global transferability and valuation. Assuring quality of online education takes a commitment and concerted efforts from many parties. The establishment of ICE Institute for online education in Indonesia is a remarkable first step in online education and needs to be further developed.

\section{References}

Allen, I.E., and J. Seaman. 2013. Changing course: Ten years of tracking online education in the United States. Boston: Babson Survey Research Group and Quahog Research Group LLC.

Andi.Link. Hootsuite (we are social): Indonesian digital report 2020. https://andi.link/hootsuitewe-are-social-indonesian-digital-report-2020/.

Badan Akreditasi Nasional Perguruan Tinggi. https://www.banpt.or.id/.

Belawati, T. 2020. Online learning in Indonesia during pandemic of Covid-19. Paper presented in the Seminar on Teaching-Learning in the Time of Pandemic: Role of Online Learning. 21-22 April 2020. Universitas Terbuka.

Belawati, T., and Nizam, eds. 2020. Potret pendidikan tinggi di masa Covid-19 (The portrait of higher education during Covid-19). Jakarta: Direktorat Jenderal Pendidikan Tinggi. 
Chaeruman, U.A. 2018. 6 lessons learned SPADA Indonesia: Its implementation as massive open online course in higher education. Paper presented at the International Symposium on Distance and E-Learning. 3-5 December 2018. Bali.

countryeconomy.com. Indonesia GDP-Gross domestic product. https://countryeconomy.com/ gdp/indonesia?year=2019.

Gullapalli, S., and P. Ren. 2019. ICE Institute and digital education in Indonesia. Official Presentation to the Ministry of Research, Technology and Higher Education by Darden School of Business, University of Virginia. 19 December 2019. Jakarta. http://onlinelearning.binus.ac. id/2019/03/12/binus-online-learning-datang-kembali-di-middle-east-qatar-uae-bahrain-oman/.

Haruka Edu. Solusi Teknologi Edukasi Bagi Semua. https://harukaedu.com/.

Indonesia-X. https://www.indonesiax.co.id/.

MinaNews.Net. 2019. ICE Institute, regulator pemantau siber perguruan tinggi Indonesia. August 27. https://minanews.net/ice-institute-regulator-pemantau-siber-perguruan-tinggi-indonesia/.

Ministry of Research, Technology and Higher Education (MORTHE). 2019a. Kemenristekdikti targetkan angka partisipasi kasar 50 persen. 11 March 2019. https://www.republika.co.id/berita/ pendidikan/dunia-kampus/19/03/11/po7dhq428-kemenristekdikti-targetkan-angka-partisipasikasar-50-persen.

MORTHE. 2019b. Panduan pembukaan program studi pendidikan jarak jauh pada perguruan tinggi. http://silemkerma.ristekdikti.go.id/portal/panduan_aplikasi.

MORTHE. 2019c. Arsitektur konseptual ICE Institute: proses - aplikasi - database - teknologi. Concept paper presented by Pannen, P., ICE Institute Development Team Chairman to the Minister of Research, Technology and Higher Education. May 2019.

Office of the Higher Education Commission. 2016. Executive summary of the framework of the second 15-year long range plan on higher education of Thailand (2008-2022). http://www.mua. go.th/users/bpp/developplan/download/long_range_plan/executive_report_eng.pdf.

Pangkalan Data Perguruan Tinggi. https://pddikti.kemdikbud.go.id/.

Pannen, P. 2015. Online lecturers' experience: A reflection. Paper presented at the Global Learn 2015. 16-17 April 2015. Berlin. https://www.learntechlib.org/primary/p/150865/. Accessed 9 January 2021.

Pannen, P. 2019. Indonesia online education and quality assurance. Paper presented at the Higher Education Dialogue on the ASEAN Vision 2025. 29-30 April 2019. Bangkok.

Pannen, P., and R.D. Riyanti. 2017. Digital and distance learning in higher education in Indonesia: moving forward. Paper presented at the ICDE World Conference on Online Learning Teaching in a Digital Age-Re-thinking Teaching \& Learning. 16-19 October 2017. Toronto.

Protopsaltis, S., and S. Baumi. 2019. Does online education live up to its promise? A look at the evidence and implications for federal policy. https://mason.gmu.edu/ sprotops/OnlineEd.pdf.

Rajendram, R. 2014. Government boost for online learning. http://www.thestar.com.my/News/Edu cation/2014/10/05/Govt-boost-for-online-learning/.

Rivard, R. 2013. Measuring the MOOC dropout rate: Inside higher education. https://www.ins idehighered.com/news/2013/03/08/researchers-explore-who-taking-moocs-and-why-so-manydrop-out.

Theeraroungchaisri, A., and J. Khlaisang. 2019. Thai MOOC sustainability: Alternative credentials for digital age learners. In Proceedings of Work in Progress Papers of the Research, Experience and Business Tracks at EMOOCs 2019 co-located with the (European MOOCs Stakeholders Submmit 2019) Conference. 20-22 May 2019. Naples, Italy. http://ceur-ws.org/Vol-2356/experi ence_short20.pdf.

United Nations Educational, Scientific and Cultural Organization (UNESCO). 2020a. COVID-19 and higher education: Today and tomorrow impact analysis-Policy responses and recommendations. Paris. http://www.iesalc.unesco.org/en/wp-content/uploads/2020/05/COVID19-EN-130520.pdf. 
UNESCO. 2020b. Education in a post-COVID world: Nine ideas for public action. Paris: International Commission on the Futures of Education. https://unesdoc.unesco.org/ark:/48223/ pf0000373717/PDF/373717eng.pdf.multi.

Worldometer. Indonesia Population. https://www.worldometers.info/world-population/indonesiapopulation/.

The opinions expressed in this chapter are those of the author(s) and do not necessarily reflect the views of the Asian Development Bank, its Board of Directors, or the countries they represent.

Open Access This chapter is licensed under the terms of the Creative Commons Attribution-NonCommercial 3.0 IGO license (http://creativecommons.org/licenses/by-nc/3.0/igo/) which permits any noncommercial use, sharing, adaptation, distribution and reproduction in any medium or format, as long as you give appropriate credit to the Asian Development Bank, provide a link to the Creative Commons license and indicate if changes were made.

Any dispute related to the use of the works of the Asian Development Bank that cannot be settled amicably shall be submitted to arbitration pursuant to the UNCITRAL rules. The use of the Asian Development Bank's name for any purpose other than for attribution, and the use of the Asian Development Bank's logo, shall be subject to a separate written license agreement between the Asian Development Bank and the user and is not authorized as part of this CC-IGO license. Note that the link provided above includes additional terms and conditions of the license.

The images or other third party material in this chapter are included in the chapter's Creative Commons license, unless indicated otherwise in a credit line to the material. If material is not included in the chapter's Creative Commons license and your intended use is not permitted by statutory regulation or exceeds the permitted use, you will need to obtain permission directly from the copyright holder.

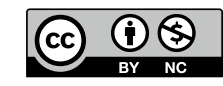

